\title{
Pengaruh Teknik Tiru Model Berbasis Model Problem Based Learning Terhadap Keterampilan Memproduksi Teks Negosiasi Siswa Kelas X SMK Negeri 1 Sintuk Toboh Gadang
}

\author{
Bunga Febrimora Hendri ${ }^{1}$, Mimi Silvia ${ }^{2}$ \\ Prodi Pendidikan Bahasa dan Sastra Indonesia \\ STKIP YDB Lubuk Alung, Sumatera Barat \\ bungafebrimora@rocketmail.com
}

\begin{abstract}
Abstrak
Penelitian ini bertujuan untuk Pertama, mendeskripsikan tingkat keterampilan memproduksi teks negosiasi siswa kelas X SMK Negeri 1 Sintuk Toboh Gadang sebelum diterapkan teknik Tiru Model berbasis model Problem Based Learning. Kedua, mendeskripsikan tingkat keterampilan memproduksi teks negosiasi siswa kelas X SMK Negeri 1 Sintuk Toboh Gadang sesudah diterapkan teknik Tiru Model berbasis model Problem Based Learning. Ketiga, menganalisis pengaruh penerapan teknik Tiru Model berbasis model Problem Based Learning terhadap keterampilan memproduksi teks negosiasi siswa kelas X SMK Negeri 1 Sintuk Toboh Gadang. Metode penelitian yang diterapkan adalah metode deskriptif analisis. Desain penelitian ini adalah pre-test and post-testone group design. Populasi pada penelitian ini adalah siswa kelas X SMK Negeri 1 Sintuk Toboh Gadang yang terdaftar pada tahun pelajaran 2017 sebanyak 442 siswa. Sampel pada penelitian adalah siswa kelas X TKJ-1 yang berjumlah 30 siswa. Berdasarkan hasil penelitian dapat disimpulkan sebagai berikut ini. Pertama, keterampilan memproduksi teks negosiasi sebelum diterapkan teknik Tiru Model berbasis model Problem Based Learning berada pada kualifikasi “cukup" $(63,06)$. Kedua, keterampilan memproduksi teks negosiasi sesudah diterapkan teknik Tiru Model berbasis model Problem Based Learning berada pada kualifikasi "lebih dari cukup" $(75,66)$. Ketiga, terdapat pengaruh penerapan teknik Tiru Model berbasis model Problem Based Learning terhadap keterampilan memproduksi teks negosiasi siswa kelas X SMK Negeri 1 Sintuk Toboh Gadang setelah dilakukan uji-t pada taraf 0,95, diperoleh $t_{\text {hitung }}>t_{\text {tabel }}$ atau 5,36>1,75.Jadi dapat dikatakan bahwa $\mathrm{H}_{\mathrm{o}}$ ditolak dan $\mathrm{H}_{\mathrm{i}}$ diterima.
\end{abstract}

Kata kunci: Pengaruh, Teknik Tiru Model Berbasis Model Problem Based Learning

\begin{abstract}
This study aims to First, describe the level of skill in producing negotiating text for the tenth grade students of State Vocational High School 1 Sintuk Toboh Gadang before applying the Model Imitation technique based on the Problem Based Learning model. Secondly, it describes the level of skill in producing negotiating text for the tenth grade students of State Vocational High School 1 of Toboh Gadang Syntax after applying the Model Mock Technique based on the Problem Based Learning model. Third, analyzing the influence of the application of Model Mock Technique based on the Problem Based Learning model on the skills of producing negotiating text for tenth grade students of State Vocational School 1 Sintuk Toboh Gadang. The research method applied is descriptive analysis method. The design of this study was the pretest and post-testone group design. The population in this study were the tenth grade students of State Vocational High School 1 of Sintuk Toboh Gadang which were registered in the 2017 academic year as many as 442 students. The sample in the study were students of class X TKJ-1 totaling 30 students. Based on the results of the study can be concluded as follows. First, the skill to produce negotiating text before applying the Model Mock Technique based on the Problem Based Learning model is in the "enough" qualification (63.06). Secondly, the skill to produce negotiating text after applying the Model-based Modeling Technique is in the "more than enough" qualification (75.66). Third, there is the influence of the application of the Model Mock technique based on the Problem Based Learning model of the skill to produce negotiating text for the tenth grade students of SMK Negeri 1 Sintuk Toboh Gadang after the $t$-test at the level of 0.95 , obtained t count $>t$ table or 5.36> 1.75 . So it can be said that Ho is rejected and Hi is accepted.
\end{abstract}

Key words: Influence, Modeling Techniques Based On Problem Based Learning Models 


\section{PENDAHULUAN}

Keterampilan memproduksi merupakan suatu proses yang dilakukan siswa dalam menciptakan sebuah karya. Keterampilan tersebut disajikan siswa melalui ide, gagasan, atau pengetahuannya terhadap karya yang diciptakannya. Dalam hal ini, karya tersebut adalah produk bahasa berupa teks dengan tujuannya secara kontekstual. Teks tersebut dihasilkan melalui karya tulis yang diciptakan oleh siswa.

Berdasarkan isi dari Kurikulum 2013 pada pembelajaran bahasa Indonesia, teks memiliki ragam jenisnya terkait dengan karakteristik teks tersebut. Pembelajaran bahasa Indonesia berbasis teks wajib dipelajari siswa dengan menerapkan prinsip bahwa bahasa bersifat fungsional, yaitu penggunaan bahasa yang tidak pernah dapat dilepaskan dari konteks karena bentuk bahasa yang digunakan itu mencerminkan ide, sikap, nilai, dan ideologi penggunanya. Dengan demikian, melalui prinsip tersebut perlu disadari oleh siswa bahwa dalam pembelajaran berbasis teks, bahasa Indonesia diajarkan bukan sekadar sebagai pengetahuan bahasa, melainkan sebagai teks yang mengemban fungsi untuk menjadi sumber aktualisasi diri penggunanya pada konteks sosial, budaya, dan akademis.

Jenis-jenis teks yang wajib dipelajari siswa, khususnya siswa kelas $\mathrm{X}$ tingkat SMK adalah teks anekdot, teks eksposisi, teks laporan hasil observasi, teks prosedur, teks hikayat, teks negosiasi, dan teks cerita pendek. Pada penelitian yang penulis lakukan, salah satu teks yang dipelajari siswa adalah teks negosiasi.

Didalam KBBI (2008:957) negosiasi dapat diartikan sebagai: pertama, proses tawarmenawar dengan jalan berunding guna mencapai kesepakatan bersama antara satu pihak (kelompok atau organisasi) dan pihak (kelompok atau organisasi) yang lain. Kedua, penyelesaian sengketa secara damai melalui perundingan antara pihak yang bersengketa.

Menurut Kosasih, (2014: 86) negosiasi adalah bentuk interaksi sosial yang berfungsi untuk mencapai kesepakatan diantara pihakpihak yang mempunyai kepentingan yang berbeda. Kemendikbud (2015: 149) juga menjelaskan negosiasi adalah bentuk interaksi sosial yang berfungsi untuk mencari penyelesaian bersama di antara pihak-pihak yang mempunyai perbedaan kepentingan.

Berdasarkan uraian diatas, dapat disimpulkan bahwa teks negosiasi merupakan teks yang menerangkan bentuk interaksi sosial atau proses tawar-menawar dengan jalan berunding untuk memberi atau menerima dengan tujuan mencapai kesepakatan bersama antara satu pihak dengan pihak yang lain yang mempunyai perbedaan kepentingan.

Kemendikbud (2013 : 141) menjelaskan tentang struktur yang terdapat pada teks negosiasi, yang terdiri atas tiga bentuk berupa: (1) pembukaan mengenai isu permasalahan, (2) isi mengenai pengajuan dan penawaran, dan (3) penutup mengenai kata kesepakatan, kepuasan, dan ketidakpuasan. Kemendikbud (2015 : 156) 
juga menjelaskan struktur teks negosiasi adalah orientasi, pengajuan, penawaran dan persetujuan.

Teks negosiasi tercantum di dalam Kurikulum 2013 SMA kelas X, padaKompetensi Inti (KI) 4 yang berbunyi“Mengolah, menalar dan menyaji dalam ranah konkret dan ranah abstrak terkait dengan pengembangan dari yang dipelajarinya di sekolah secara mandiri, dan mampu menggunakan metode sesuai dengan kaidah keilmuan, dengan Kompetensi Dasar (KD) 4.2 yang berbunyi“"Memproduksi teks negosiasi yang koheren sesuai dengan karakteristik teks yang akan dibuat baik secara lisan maupun tulis”. Dengan demikian, sesuai tuntutan KI dan KD tersebut, siswa diharapkan terampil dalam menuliskan teks negosiasi sesuai dengan fungsi dan tujuannya secara kontekstual”.

Masalah yang ditemukan disekolah, nilai yang diperoleh siswa dalam menulis teks negosiasi masih rendah (dibawah KKM yang telah ditentukan, yaitu 75). Hal tersebut disebabkan karena, Pertama, kurangnya minat siswa belajar menulis teks negosiasi karena siswa berpendapat bahwa menulis sebuah teks negosiasi merupakan hal yang susah.Kedua, kurangnya kemampuan siswa dalam memproduksi teks negosiasi, karena siswa hanya sebagian yang menyukai teks negosiasi. Ketiga, siswa mengalami kesulitan dalam mengembangkan gagasandan imajinasinya dalam memproduksi teks negosiasi dan masih kesulitan memahami struktur dari teks negosiasi. Keempat, guru belum pernah menerapkan teknik Tiru Model berbasis model Problem Based Learning.

Sebagai bahan alternatif untuk meningkatkan keterampilan mem-produksi siswa, khususnya dalam memproduksi teks negosiasi maka peneliti mencoba menerapkan teknik Tiru Model berbasis Problem Based Learning. Dengan menerapkan teknik ini akan membantu siswa lebih kreatif dalam memproduksi sebuah teks, terutama memproduksi teks negosiasi. Alasan peneliti menerapkanteknik Tiru Model berbasis Problem Based Learning terhadap keterampilan memproduksi teks negosiasisiswa kelas $\mathrm{X}$ di SMKNegeri1 Sintuk Toboh Gadangadalah teknik Tiru Model berbasis Problem Based Learning belum pernah diterapkan di kelas X, mata pelajaran bahasa Indonesia.

Berdasarkan uraian di atas, penulis perlu melakukan penelitian dengan judul "Pengaruh Teknik Tiru Model Berbasis Problem Based Learning terhadap Keterampilan Memproduksi Teks Negosiasi Siswa Kelas X SMK Negeri 1 Sintuk Toboh Gadang”.

\section{METODE PENELITIAN}

Jenis penelitian yang digunakan adalah penelitian kuantitatif. Pada penelitian ini, data yang dikumpulkan berupa angka-angka, yaitu skor keterampilan memproduksi teks negosiasi siswa kelas X SMKNegeri 1 Sintuk Toboh Gadang sebelum dan sesudah diterapkan teknik Tiru Modelberbasis model Problem Based Learning. 
Data dalam penelitian ini adalah skor tes keterampilan memproduksi teks negosiasi siswa kelas X SMK Negeri 1Sintuk Toboh Gadang sebelum dan sesudah diterapkan teknik Tiru Model berbasis model Problem Based Learning. Dalam pengumpulan data langkah kerja yang dilakukan adalah sebagai berikut ini. Pertama, guru membagikan lembaran tes kepada siswa dan menugasi siswa memproduksi teks negosiasi melalui kegiatan menulisnya (pretest). Kedua, guru memberikan perlakuan dengan menerapkan teknik Tiru Model berbasis model Problem Based Learning, dan menugaskan siswa untuk latihan menulis teks negosiasi. Ketiga, guru menugasi siswa mengerjakan tes akhir (posttest) memproduksi teks negosiasi sesudah diterapkan teknik Tiru Model berbasis model Problem Based Learning. Setelah selesai, lembaran kerja pretest dan posttest siswa dikumpulkan.

\section{HASIL DAN PEMBAHASAN}

Hasi dari penelitian ini, dideskripsikan sebagai berikut.

1. Keterampilan Memproduksi Teks Negosiasi Siswa Kelas X SMKN 1 Sintuk Toboh Gadang sebelum Diterapkan Teknik Tiru Model Berbasis Model Problem Based Learning (PBL) secara Umum

Tabel Klasifikasi

\begin{tabular}{ccccc}
\hline No & $\begin{array}{c}\text { Rentangan } \\
\text { Nilai }\end{array}$ & Kualifikasi & $\begin{array}{c}\text { Frekuen } \\
\text { si }\end{array}$ & $\begin{array}{c}\text { Persentase } \\
(\%)\end{array}$ \\
\hline 1. & $96-100$ & Sempur-na & 0 & 0 \\
\hline 2. & $86-95$ & $\begin{array}{c}\text { Baik } \\
\text { sekali }\end{array}$ & 0 & 0 \\
\hline 3. & $76-85$ & Baik & 2 & 6,67 \\
\hline 4. & $66-75$ & $\begin{array}{c}\text { Lebih dari } \\
\text { cukup }\end{array}$ & 12 & 40 \\
\hline 5. & $56-65$ & Cukup & 13 & 43,33 \\
\hline
\end{tabular}

http://ejournal.unikama.ac.id/index.php/irnspirasi

\begin{tabular}{ccccc}
\hline 6. & $46-55$ & $\begin{array}{c}\text { Hampir } \\
\text { cukup }\end{array}$ & 3 & 10 \\
\hline 7. & $36-45$ & Kurang & 0 & 0 \\
\hline 8. & $26-35$ & $\begin{array}{c}\text { Kurang } \\
\text { sekali }\end{array}$ & 0 & 0 \\
\hline 9. & $16-25$ & Buruk & 0 & 0 \\
\hline 10. & $0-15$ & $\begin{array}{c}\text { Buruk } \\
\text { sekali }\end{array}$ & 0 & 0 \\
\hline & & 30 & 100 \\
\hline
\end{tabular}

Berdasarkan Tabel di atas, diperoleh gambaran keterampilan memproduksi teks negosiasi siswa kelas X SMK Negeri 1 Sintuk Toboh Gadang sebelum diterapkan teknik Tiru Model berbasis model Problem Based Learning secara umum terdiri atas empat klasifikasi. Pertama, kualifikasi baik berjumlah 2 orang siswa (6,67\%). Kedua, kualifikasi lebih dari cukup berjumlah 12 orang siswa (40\%). Ketiga, kualifikasi cukup berjumlah 13 orang siswa $(43,33 \%)$. Keempat, kualifikasi hampir cukup berjumlah 3 orang siswa (10\%).

Hasil pada data diatas diperoleh dari perhitungan skor per indikator yang telah ditentukan. Kosasih (2014:89) yang mengatakan bahwa secara umum, teks negosiasi dibentuk oleh tiga bagian yakni pembukaan, isi dan penutup.

2. Keterampilan Memproduksi Teks Negosiasi Siswa Kelas X SMKN 1 Sintuk Toboh Gadang sesudah Diterapkan Teknik Tiru Model Berbasis Model Problem Based Learning (PBL) secara Umum

Tabel Klasifikasi

\begin{tabular}{cclcc}
\hline No. & $\begin{array}{c}\text { Rentang } \\
\text { an Nilai }\end{array}$ & $\begin{array}{c}\text { Kualifika } \\
\text { si }\end{array}$ & $\begin{array}{c}\text { Frekuen } \\
\text { si }\end{array}$ & $\begin{array}{c}\text { Persen } \\
\text { ta } \\
\text { se }(\%)\end{array}$ \\
\hline 1. & $96-100$ & Sempurna & 0 & 0 \\
\hline 2. & $86-95$ & Baik sekali & 4 & 13,33 \\
\hline 3. & $76-85$ & Baik & 12 & 40 \\
\hline 4. & $66-75$ & $\begin{array}{l}\text { Ledih dari } \\
\text { cukup }\end{array}$ & 10 & 33,34 \\
\hline 5. & $56-65$ & Cukup & 4 & 13,33 \\
\hline
\end{tabular}


JIP, Vol.8, No. 2, Edisi Agustus 2018, Hal: 68-76

Bunga Febrimora Hendri ${ }^{1}$, Mimi Silvia ${ }^{2}$

\begin{tabular}{cclll}
\hline 6. & $46-55$ & $\begin{array}{l}\text { Hampir } \\
\text { cukup }\end{array}$ & 0 & 0 \\
\hline 7. & $36-45$ & Kurang & 0 & 0 \\
\hline 8. & $26-35$ & $\begin{array}{l}\text { Kurang } \\
\text { sekali }\end{array}$ & 0 & 0 \\
\hline 9. & $16-25$ & Buruk & 0 & 0 \\
\hline 10. & $0-15$ & $\begin{array}{l}\text { Buruk } \\
\text { sekali }\end{array}$ & 0 & 0 \\
\hline & & & 30 & 100 \\
\hline
\end{tabular}

Berdasarkan Tabel diatas, diperoleh gambaran keterampilan memproduksi teks negosiasi siswa kelas X SMK Negeri 1 Sintuk Toboh Gadang sesudah diterapkan teknik Tiru Model berbasis model Problem Based Learning secara umum terdiri atas empat klasifikasi. Pertama, kualifikasi baik sekali berjumlah 4 orang siswa (13,33\%). Kedua, kualifikasi baik berjumlah 12 orang siswa (40\%). Ketiga, kualifikasi lebih dari cukup berjumlah 10 orang siswa (33,34\%). Keempat, kualifikasi cukup berjumlah 4 orang siswa $(13,33 \%)$.

Hasil pada data diatas diperoleh dari perhitungan skor per indikator yang telah ditentukan. Kosasih (2014:89) yang mengatakan bahwa secara umum, teks negosiasi dibentuk oleh tiga bagian yakni pembukaan, isi dan penutup.

3. Pengaruh Penerapkan Teknik Tiru Model Berbasis Model Problem Based Learning (PBL)Terhadap Keterampilan Memproduksi Teks Negosiasi Siswa Kelas X SMKN 1 Sintuk Toboh Gadang secara Umum

Data yang telah dianalisis, ditarik kesimpulan dengan cara membuktikan hipotesis apakah diterima atau ditolak. Untuk mengetahui apakah hipoteisis ditolak atau diterima perlu dilakukan uji normalitas dan uji homogenitas.
Kemudian melakukan uji kesamaan dua ratarata.

a. Uji Normalitas Data sebelum dan sesudah Diterapkan Teknik Tiru ModelBerbasis Model Problem Based Learning

Uji normalitas data adalah uji yang dilakukan untuk membuktikan apakah sebuah variabel memiliki sebaran data yang berdistribusi normal atau tidak. Uji normalitas data dilakukan dengan uji Lilliefors. Berdasarkan uji normalitas yang dilakukan, diperoleh $\mathrm{L}_{0}$ dan $\mathrm{L}_{\mathrm{t}}$ pada taraf signifikansi 0,05 untuk $\mathrm{n}=30$ dan $\mathrm{n}=30$, seperti pada tabel berikut ini.

\section{Tabel}

Uji Normalitas Data sebelum Diterapkan Teknik Tiru Model Berbasis Model Problem Based Learning

\begin{tabular}{ccccc}
\hline $\begin{array}{c}\text { Jumlah } \\
(\mathbf{N})\end{array}$ & $\begin{array}{c}\text { Taraf } \\
\text { Nyata }\end{array}$ & $\mathbf{L}_{\mathbf{0}}$ & $\mathbf{L}_{\mathbf{t}}$ & Keterangan \\
\hline 30 & 0,05 & 0,6873 & 0,159 & Berdistribusi \\
& & & & Normal \\
\hline
\end{tabular}

Berdasarkan Tabel tersebut, disimpulkan bahwa data sebelum diterapkan teknik Tiru Model berbasis model Problem Based Learning berdistribusi normal pada taraf signifikansi 0,05 untuk $\mathrm{n}=30$ karena $\mathrm{L}_{0}<\mathrm{L}_{\text {tabel }}(0,6873<0,159)$.

\section{Tabel}

Uji Normalitas Data sesudah Diterapkan Teknik Tiru ModelBerbasis Model Problem Based Learning

\begin{tabular}{ccccc}
\hline $\begin{array}{c}\text { Jumlah } \\
(\mathbf{N})\end{array}$ & $\begin{array}{c}\text { Taraf } \\
\text { Nyata }\end{array}$ & $\mathbf{L}_{\mathbf{0}}$ & $\mathbf{L}_{\mathbf{t}}$ & Keterangan \\
\hline 30 & 0,05 & 0,2770 & 0,173 & Berdistribusi \\
& & & & Normal \\
\hline
\end{tabular}

Demikian juga dengan data sesudah diterapkan teknik Tiru Model berbasis model 
Problem Based Learningyang berdistribusi normal karena $\mathrm{L}_{0}<\mathrm{L}_{\text {tabel }}(0,2770<0,173)$.

\section{b. Uji Homogenitas Data sebelum dan sesudah Diterapkan Teknik Tiru ModelBerbasis Model Problem Based Learning}

Uji homogenitas data dilakukan untuk mengetahui apakah dari beberapa kelompok data penelitian memiliki varian yang homogen atau tidak. Berdasarkan uji homogenitas data yang dilakukan, diperoleh $\mathrm{F}_{\text {hitung }}$ dan $\mathrm{F}_{\text {tabel }}$ pada taraf signifikansi 0,05 dengan $\mathrm{dk}=(\mathrm{n}-1)$ seperti pada tabel berikut ini.

Tabel

Uji Homogenitas Data sebelum Diterapkan Teknik Tiru ModelBerbasis Model Problem Based Learning

\begin{tabular}{ccccc}
\hline $\begin{array}{c}\text { Jum- } \\
\text { lah }\end{array}$ & $\begin{array}{c}\text { Taraf } \\
\text { Nyata }\end{array}$ & $\mathbf{F}_{\text {hitung }}$ & $\mathbf{F}_{\text {tabel }}$ & Keterangan \\
$(\mathbf{N})$ & & & & \\
\hline 30 & 0,05 & 1,66 & 1,74 & Homogen \\
\hline
\end{tabular}

Tabel

Uji Homogenitas Data sesudah Diterapkan Teknik Tiru Model Berbasis Model Problem Based Learning

\begin{tabular}{c|c|c|c|c}
\hline $\begin{array}{c}\text { Jum- } \\
\text { lah } \\
(\mathbf{N})\end{array}$ & $\begin{array}{c}\text { Taraf } \\
\text { Nyata }\end{array}$ & $\mathbf{F}_{\text {hitung }}$ & $\mathbf{F}_{\text {tabel }}$ & Keterangan \\
\hline 31 & 0,05 & 1,72 & 1,77 & Homogen \\
\hline
\end{tabular}

Berdasarkan Tabel tersebut, disimpulkan bahwa kelompok data memiliki homogenitas pada taraf signifikansi 0,05 dengan $\mathrm{dk}=\left(\mathrm{n}_{1}+\right.$ $\mathrm{n}_{2)}-2$, karena nilai $\mathrm{F}_{\text {hitung }}<\mathrm{F}_{\text {tabel }}(1,66<1,74)$.

\section{c. Uji Hipotesis}

Setelah melakukan uji normalitas dan uji homogenitas, dapat diketahui bahwa skor tes

hasil tulisan siswa sebelum dan sesudah diterapkan teknik Tiru Model berbasis model Problem Based Learning mempunyai varian yang homogen. Untuk menentukan memproduksi teks negosiasi sebelum diterapkan teknik Tiru Model berbasis model Problem Based Learning dengan keterampilan memproduksi teks negosiasi sesudah diterapkan teknik Tiru Model berbasis model Problem Based Learning pada siswa kelas X SMK Negeri 1 Sintuk Toboh Gadang, maka harus dilakukan uji hipotesis. Uji hipotesis tersebut dilakukan berdasarkan data perbandingan pada tabel sebagai berikut.

\section{Tabel}

Perbedaaan Keterampilan Memproduksi Teks NegosiasiSiswa Kelas

X SMK Negeri 1 Sintuk Toboh Gadangsebelum dan sesudah Diterapkan Teknik Tiru Model BerbasisProblem Based Learning

\begin{tabular}{|c|c|c|c|c|c|}
\hline No & $\begin{array}{c}\text { Kode } \\
\text { Sampel }\end{array}$ & $\mathbf{X}_{1}$ & $\mathbf{X}_{1}{ }^{2}$ & $\mathbf{X}_{2}$ & $\mathrm{X}_{2}{ }^{2}$ \\
\hline 1 & S001 & 70 & 4900 & 83 & 6889 \\
\hline 2 & S002 & 66 & 4356 & 79 & 6241 \\
\hline 3 & S003 & 58 & 3364 & 83 & 6889 \\
\hline 4 & S004 & 58 & 3364 & 79 & 6241 \\
\hline 5 & S005 & 58 & 3364 & 79 & 6241 \\
\hline 6 & S006 & 58 & 3364 & 83 & 6889 \\
\hline 7 & S007 & 58 & 3364 & 75 & 5625 \\
\hline 8 & S008 & 58 & 3364 & 75 & 5625 \\
\hline 9 & S009 & 50 & 2500 & 58 & 3364 \\
\hline 10 & S010 & 58 & 3364 & 75 & 5625 \\
\hline 11 & S011 & 75 & 5625 & 79 & 6241 \\
\hline 12 & S012 & 58 & 3364 & 87 & 7569 \\
\hline 13 & S013 & 58 & 3364 & 83 & 6889 \\
\hline 14 & S014 & 58 & 3364 & 75 & 5625 \\
\hline 15 & S015 & 50 & 2500 & 83 & 6889 \\
\hline 16 & S016 & 83 & 6889 & 66 & 4356 \\
\hline
\end{tabular}


JIP, Vol.8, No. 2, Edisi Agustus 2018, Hal: 68-76

Bunga Febrimora Hendri ${ }^{1}$, Mimi Silvia ${ }^{2}$

\begin{tabular}{|c|c|c|c|c|c|}
\hline 17 & S017 & 66 & 4356 & 75 & 5625 \\
\hline 18 & S018 & 66 & 4356 & 83 & 6889 \\
\hline 19 & S019 & 58 & 3364 & 58 & 3364 \\
\hline 20 & S020 & 70 & 4900 & 87 & 7569 \\
\hline 21 & S021 & 83 & 6889 & 87 & 7569 \\
\hline 22 & S022 & 66 & 4356 & 75 & 5625 \\
\hline 23 & S023 & 58 & 3364 & 58 & 3364 \\
\hline 24 & S024 & 66 & 4356 & 79 & 6241 \\
\hline 25 & S025 & 75 & 5625 & 87 & 7569 \\
\hline 26 & S026 & 58 & 3364 & 66 & 4356 \\
\hline 27 & S027 & 70 & 4900 & 66 & 4356 \\
\hline 28 & S028 & 66 & 4356 & 58 & 3364 \\
\hline 29 & S029 & 66 & 4356 & 66 & 4356 \\
\hline 30 & S030 & 50 & 2500 & 83 & 6889 \\
\hline \multicolumn{2}{|c|}{ Jumlah } & 1892 & 121452 & 2270 & 174334 \\
\hline \multicolumn{2}{|c|}{ Rata-rata } & 63,06 & 4048,4 & 75,66 & 5811,13 \\
\hline \multicolumn{2}{|c|}{ SD } & 8,57 & & 9,42 & \\
\hline
\end{tabular}

Berdasarkan data pada Tabel 24, dapat diuraikan perbandingan keterampilan memproduksi teks negosiasi siswa kelas $\mathrm{X}$ SMK Negeri 1 Sintuk Toboh Gadang sebelum dan sesudah diterapkan teknik Tiru Model berbasis model Problem Based Learning. Untuk mencari perbandingan tersebut akan digunakan rumus $\mathrm{t}$ tes. Namun, sebelumnya akan ditentukan taksiran variannya $\left(S^{2}\right)$. Lebih jelasnya akan dipaparkan dalam rumus berikut ini.

$S^{2}=\sum X_{1}^{2}-\frac{\frac{\left(\sum X_{1}\right)^{2}}{N^{1}}+\sum X_{2}^{2}-\frac{\left(\sum X_{2}\right)^{2}}{N^{1}}}{\left(N_{1}+N_{2}\right)-2}$

$S^{2}=121452-\frac{\frac{(1892)^{2}}{30}+174334-\frac{(2270)^{2}}{30}}{(30+30)-2}$

$S^{2}=121452-\frac{\frac{3579664}{30}+174334-\frac{5152900}{30}}{58}$

$S^{2}=\frac{121452-119322,13+174334-171763,33}{58}$

$S^{2}=2129,87+2570,67$

$S^{2}=\frac{4700,54}{58}$

$S^{2}=81,04$

Berdasarkan pembahasan rumus di atas, diketahui taksiran varian adalah 81,04. Dengan demikian, dapat dicari perbandingan keterampilan mempro-duksi teks negosiasi siswa kelas X SMK Negeri 1 Sintuk Toboh Gadang sebelum dan sesudah diterapkan teknik Tiru Model berbasis model Problem Based Learning dengan rumus $\mathrm{t}$ tes berikut ini.

$$
\begin{gathered}
\mathrm{t}=\frac{\left[X_{1}-X_{2}\right]}{\sqrt{\left(\frac{s^{2}}{n_{1}}\right)+\left(\frac{s^{2}}{n_{2}}\right)}} \\
\mathrm{t}=\frac{75,66-63,06}{\sqrt{\left(\frac{81,04}{30}\right)+\left(\frac{81,04}{30}\right)}} \\
t=\frac{12,6}{\sqrt{(2,73)+(2,73)}} \\
t=\frac{12,6}{\sqrt{5,46}}=\frac{12,6}{2,35}=5,36 \\
t_{\text {hitung }}=\mathbf{5 , 3 6}
\end{gathered}
$$

Berdasarkan nilai $\mathrm{t}$ yang diperoleh, diketahui bahwa nilai t kedua variabel dalam penelitian ini adalah 5,36. Nilai t yang diperoleh dari rumus tersebut, kemudian dilanjutkan dengan membandingkan nilat $\mathrm{t}$ hitung dengan $\mathrm{t}$ tabel pada taraf signifikan 0,05. Uji hipotesis lebih jelasnya dapat dilihat pada tabel di bawah ini.

Tabel Uji Hipotesis

\begin{tabular}{ccc}
\hline T hitung & $\mathrm{n}-2$ & T tabel \\
\cline { 3 - 3 } & & $\mathrm{P} 0,95$ \\
\hline 5,36 & 28 & 1,70 \\
\hline
\end{tabular}


JIP, Vol.8, No. 2, Edisi Agustus 2018, Hal: 68-76

Bunga Febrimora Hendri ${ }^{1}$, Mimi Silvia ${ }^{2}$

Berdasarkan hasil pengujian hipotesis tersebut, dapat disismpulkan bahwa terdapat perbedaan keterampilan memproduksi teks negosiasi siswa kelas X SMK Negeri 1 Sintuk Toboh Gadang sebelum dan sesudah diterapkan teknik Tiru Model berbasis model Problem Based Learning, pada taraf signifikan 0,05 dengan dk n-2 (30-2=28). Berdasarkan hal tersebut, dapat disimpulkan bahwa $H_{O}$ ditolak dan $H_{1}$ diterima karena hasil pengujian membuktikan bahwa $T_{\text {hitung }}$ lebih besar $T_{\text {tabel }}$ yaitu $3,46>1,70$.

\section{SIMPULAN DAN SARAN}

Berdasarkan hasil penelitian yang penulis lakukan, dapat disimpulkan tiga hal sebagai berikut ini. Pertama, keterampilan memproduksi teks negosiasisiswa kelas X SMK Negeri 1 Sintuk Toboh Gadangsebelum diterapkan teknik Tiru Model berbasis model Problem Based Learningdiperoleh rata-rata hitung (M) adalah 63,06 dan terkategorikan cukup, karena (M) berada pada tingkat penguasaan 56-65\% pada skala 10 .

Kedua,keterampilan mem-produksi teks negosiasisiswa kelas X SMK Negeri 1 Sintuk Toboh Gadangsesudah diterapkan teknik Tiru Model berbasis model Problem Based Learningdiperoleh rata-rata hitung (M) adalah 75,66 dan terkategorikanlebih dari cukup, karena (M) berada pada tingkat penguasaan 66$75 \%$ pada skala 10 .

Ketiga,terdapat pengaruh penerapan teknik Tiru Model berbasis model Problem

\section{Based Learningterhadap keterampilan} memproduksi teks negosiasisiswa kelas X SMK Negeri 1 Sintuk Toboh Gadang.Hal tersebut dapat dilihat dengan menggunakan uji-t diperoleh $t_{\text {hitung }}$ sebesar 5,36 dan $\mathrm{T}_{\text {tabel }} 1,70$ pada P 0,95. Berdasarkan hal tersebut dapat disimpulkan bahwa $\mathrm{H}_{0}$ ditolak dan $\mathrm{H}_{1}$ diterima karena hasil pengujian membuktikan bahwa $t_{\text {hitung }}$ lebih besar dari $t_{\text {tabel }}$ yaitu 5,36>1,70.

Berdasarkan simpulan di atas, diajukan tiga saran sebagai berikut ini. Pertama, kepada guru bahasa Indonesia yang mengajar di SMK Negeri1 Sintuk Toboh Gadang yaituagar menerapkan berbagai model dalam pembelajaran bahasa dan sastra Indonesia, khususnya pembelajaran keterampilan memproduksi teks negosiasi. Salah satu teknik dan model yang dapat diterapkan dalam pembelajaran keterampilan memproduksi teks negosiasi adalah teknik Tiru Modelberbasis model Problem Based. Kedua, pihak sekolah, agar menyediakan sarana dan prasarana yang lengkap untuk menunjang proses belajar mengajar di kelas. Keempat, peneliti lain, sebagai bahan rujukan untuk melakukan penelitian yang sama dan bahan pertimbangan jika melakukan penelitian yang relevan dengan penelitian pada selanjutnya.

\section{DAFTAR PUSTAKA}

Abdurrahman dan Ellya Ratna. 2003. "Evaluasi Pembelajaran Bahasa dan SastraIndonesia”. Buku Ajar. Padang: Jurusan Bahasa dan Sastra Indonesia, FBSS,UNP. 
Arikunto, Suharsimi. 2010. Prosedur Penelitian Suatu Pendekatan. Jakarta: Rineka Cipta.

Depdikbud. 2013. Materi Pelatihan Guru: Implementasi Kurikulum 2013. Jakarta: Badan Pengembangan SDM Pendidikan dan Kebudayaan.

Depdiknas. 2008. Kamus Besar Bahasa Indonesia. Gramedia Pustaka Indonesia.

Kemendikbud. 2015 "Bahasa Indonesia Wahana Pengetahuan" Buku Guru. Jakarta: Politeknik Negeri Media Kreatif.

Kosasih, E. 2014. Jenis-Jenis Teks: Analisis Fungsi, Struktur, Dan Kaidah Serta Langkah Penulisannya. Bandung: Yrama Widya.

Rusman. 2012. Model-Model Pembelajaran: Mengembangkan Profesionalisme Guru. Jakarta: Rajagrafindo Persada.

Sanjaya, Wina. 2011. Strategi Pembelajaran Berorientasi Standar Proses Pendidikan. Jakarta: Kencana. 